medRxiv preprint doi: https://doi.org/10.1101/2020.05.22.20110635; this version posted June 1, 2020. The copyright holder for this preprint

(which was not certified by peer review) is the author/funder, who has granted medRxiv a license to display the preprint in perpetuity.

It is made available under a CC-BY-ND 4.0 International license .

\title{
Analysis of Crowdsourced Metformin Tablets from Individuals Reveals Widespread Contamination with N-Nitrosodimethylamine (NDMA) in the United States
}

\author{
Qian Wu, PhD, ${ }^{1}$ Evgenia Kvitko, ${ }^{1}$ Amber Jessop, MS, ${ }^{1}$ Shannon Williams, ${ }^{1}$ Ryan C. Costantino, PharmD, \\ $\mathrm{MS},{ }^{2}$ Kaury Kucera, PhD, ${ }^{1 *}$ David Light ${ }^{1}$ \\ ${ }^{1}$ Valisure, New Haven, CT \\ ${ }^{2}$ Department of Pharmaceutical Health Service Research, University of Maryland School of Pharmacy, \\ Baltimore, MD
}

*Corresponding author: Kaury Kucera, Chief Scientific Officer, Valisure LLC, 5 Science Park, New Haven, CT 06511, USA. Email: kucera@valisure.com

\begin{abstract}
Recent reports of metformin drug products contaminated with unacceptable levels of the probable human carcinogen $\mathrm{N}$-Nitrosodimethylamine (NDMA) prompted a national sampling of post-market metformin drug products. To most broadly sample the market and minimize supply chain bias, metformin medication samples were crowdsourced directly from individuals across many states in the United States. 128 samples were received, and liquid chromatography-high resolution mass spectrometry tests for a panel of nitrosamines revealed significant levels of NDMA that trend with labeling company. $42 \%$ of all medication samples contained detectable levels of NDMA and, when scaled to maximum daily tablet dose, $36 \%$ of all medication samples contained NDMA levels exceeding the FDA daily acceptable intake limit. The highest NDMA detection from the tested samples was $1565 \mathrm{ng}$ per tablet, which, when commonly taken four times a day, is 65 times the United States Food and Drug Administration (FDA) acceptable daily intake limit. Results underscore the need for immediate product recalls of tainted medications and an overall investigation of metformin manufacturing practices.
\end{abstract}

\section{Introduction}

Metformin is one of the frontline medications used to treat type 2 diabetes and prediabetes. It is commonly prescribed when a patient exhibits consistently high blood sugar levels due to the inability of insulin to effectively transport sugar into somatic cells [1] and can be taken for extended periods of time as a maintenance medication. Metformin is prescribed as a combination medication, solution and suspension but is most commonly taken in $500 \mathrm{mg}, 750 \mathrm{mg}, 850 \mathrm{mg}$, or $1000 \mathrm{mg}$ immediate release (IR) or extended release (ER) tablets one or more times per day with a recommended maximum daily intake of $2000 \mathrm{mg}$ [2]. Approximately 78 million prescriptions were written for metformin in the United States in 2017 [3]. Some research has likely led people to use metformin off-label as an alternative treatment for prediabetes, polycystic ovarian syndrome, fatty liver disease, weight loss, dementia prevention [4], thyroid disorders, and cancer prevention [5]. Metformin is the only oral medication approved for diabetes treatment in children and has also been used to treat obesity in children and adolescents [6]. Although potential benefits of metformin are numerous, aspects of the manufacturing process could lead to contamination with carcinogenic compounds. One such contaminant, N-Nitrosodimethylamine (NDMA), a nitrosamine compound, is a probable human carcinogen according to the World Health Organization (WHO) and the International Agency for Research on Cancer [7]. Nitrosamines formed 
medRxiv preprint doi: https://doi.org/10.1101/2020.05.22.20110635; this version posted June 1, 2020. The copyright holder for this preprint (which was not certified by peer review) is the author/funder, who has granted medRxiv a license to display the preprint in perpetuity. It is made available under a CC-BY-ND 4.0 International license .

from reactive pharmaceutical products or as by-products in pharmaceutical synthesis that contaminate drug products have been extensively studied due to health risks since the 1970 s $[8,9]$. Nitrosamine compound formation and contamination is currently a global concern. These probable human carcinogens may form when manufacturers reuse solvents that are neutralized with nitrite containing compounds in later steps of drug or medication processing. One common example is the use of dimethyl formamide quenched with sodium nitrite [10]. The FDA currently lists the maximum acceptable daily intake of NDMA at $96 \mathrm{ng}[11,12]$ in accordance with the WHO's interim guidelines which were set in place in January 2020 to allow manufacturers to adjust procedures to minimize possible nitrosamine contamination [10]. After a two year transition period, European regulations are expected to place tighter limits on this chemical, indicating $30 \mathrm{ng}$ as the maximum daily intake allowed in draft guidance [13]. The United States Pharmacopeia is also designing new methods for determining and limiting the nitrosamine content of medications [14] and the FDA is continuing to investigate potential sources of contamination [15].

Instances of nitrosamine contamination were first detected in mid-2018 in angiotensin II receptor blocker (ARB) drugs and the FDA issued voluntary recalls of three batches of valsartan manufactured by Zhejiang Huahai Pharmaceuticals [16]. The initial recall was expanded to encompass several repackagers and two other ARB medications, irbesartan and losartan. Testing indicated levels of NDMA, NNitrosodiethlyamine (NDEA), and N-nitroso-N-methyl-4-aminobutyric acid (NMBA) exceeding the FDA's acceptable limits. As of September 2019, a total of 1159 potentially contaminated ARB products have been affected by recalls [17].

Reports of nitrosamine contamination has since grown to include heartburn and diabetes medications like ranitidine [18] and metformin [19]. Singapore was the first to take action against NDMA contamination in metformin, testing forty-six versions of the medication available in that country. Of those products, three were found to contain unacceptable levels of NDMA and were recalled in early December 2019 [20]. Switzerland [21] and Canada [22] soon launched their own investigations following Singapore's recall. In Switzerland, Streuli Pharma recalled twenty batches of metformin products [23] within weeks. Canada announced its initial recalls in February 2020, pulling ten batches with excessive levels of NDMA and four more with levels approaching the acceptable limit. One month later, an additional twenty-six lots were recalled as a precautionary measure [24]. Investigations are still ongoing in the European Union and the United States. The European Medicines Agency [25] and the FDA [15] each released statements in December 2019 to alert the public of their testing efforts.

On February 3, 2020, the FDA released lab results for products from seven companies and sixteen lots of metformin showing levels of NDMA below the FDA acceptable limit [19]. Notably, the FDA may acquire drug or medication samples for analysis through voluntary submission by, or seizure from, specific labeling or manufacturing companies, which can generate sampling bias [26, 27]. On March 2, 2020, an FDA citizen petition was filed by Valisure, LLC which contained lab results for twenty-two companies and thirty-eight lots of metformin showing $42 \%$ of lots contained NDMA in excess of the FDA's daily acceptable intake limit of $96 \mathrm{ng}$ [28]. Valisure acquired its samples through its licensed pharmacy that purchased the metformin from United States-based distributors. Although this approach may reduce selection bias, it is still limited to the available products from a few specific distributors in a short period of time. 
medRxiv preprint doi: https://doi.org/10.1101/2020.05.22.20110635; this version posted June 1, 2020. The copyright holder for this preprint

(which was not certified by peer review) is the author/funder, who has granted medRxiv a license to display the preprint in perpetuity.

It is made available under a CC-BY-ND 4.0 International license .

To further assess the quality of metformin and reduce selection bias as much as possible, Valisure crowdsourced samples of metformin direct from individuals in many states within the United States. The availability of testing was publicized through social media channels like Facebook and Twitter, through consumer advocate networks like The People's Pharmacy, and other means. The testing program was open to people in all states except Massachusetts and Virginia due to restrictions, and individuals whose medications were paid for by government funded healthcare programs. To our knowledge, this is the first study on the occurrence of nitrosamines in metformin products supplied across the United. States. The high levels of NDMA contamination found through this testing program underscore the need for product recalls and a much broader investigation of metformin manufacturing practices. One May 28, 2020, the FDA announced the first metformin recalls in the United States [29]. However, these recalls only focused on a subset of metformin products, those designated as ER, whereas evidence exists, including in this study, that the contamination is more widespread. Therefore, more work is likely needed to better study and monitor the quality of metformin products in the US.

\section{Materials and Methods}

In February 2020, FDA published a method titled "Liquid Chromatography-High Resolution Mass Spectrometry (LC-HRMS) Method for the Determination of NDMA in Metformin Drug Substance and Drug Product" [30]. Following the method testing principle, a modified method was validated in Valisure's ISO 17025 accredited analytical laboratory to achieve a lower limit of quantification (LOQ) and inclusion of a method for limiting the potential for analytical artifacts originating from different inactive ingredients present in different formulations of metformin tablets made by different companies [31].

Metformin Drug Product Sampling

Metformin drug product samples were crowdsourced from individuals in the United States except Massachusetts and Virginia due to those states' restrictions. Patients on government insurance programs were also excluded. Samples of two tablets per medication lot were collected and one was analyzed during a five-month period spanning December 2019 to May 2020. 12 samples were collected from December 2019 to February 2020 and 116 were collected from March 2020 to May 2020. Accepting two tablets was preferable to one to mitigate against the potential of loss of one tablet. Participating individuals used Valisure's sampling and shipping materials for sample collection and shipping. These sampling and shipping materials have been previously certified to contain no nitrosamine contaminants. The National Drug Code (NDC) of metformin drug product samples was determined by visual inspection of unique tablet imprints and referencing the drugs.com database. The cities and states where the samples were purchased were reported by those who volunteered samples for this study. Three combination products were accepted and included in dosage groups according to the metformin dose.

The formulation and current approval status for all samples was cross-referenced using the FDA Orange Book [32] and National Drug Code Directory [33].

Equipment, Supplies, and Chemicals 
medRxiv preprint doi: https://doi.org/10.1101/2020.05.22.20110635; this version posted June 1, 2020. The copyright holder for this preprint

(which was not certified by peer review) is the author/funder, who has granted medRxiv a license to display the preprint in perpetuity. It is made available under a CC-BY-ND 4.0 International license .

SCIEX EXIONLC AD high performance liquid chromatography coupled with SCIEX X500R time of flight high resolution mass spectrometry (HPLC-QToF HRMS) were purchased from SCIEX (Framingham, MA). Luna Omega PS C18 HPLC column ( $3 \mu \mathrm{m}, 4.6 \times 100 \mathrm{~mm}$ ) was purchased from Phenomenex (Torrance, CA). Certified reference material of NDMA, NDEA, N-

Nitrosodibutylamine (NDBA), and NMBA were purchased from Sigma-Aldrich (St. Louis, MO). Nethyl-N-nitroso-2-propanamine (NEIPA) and N-Nitrosodiisoporpylamine (NDIPA) were custom made and certified by Enamine (Monmouth Jct., NJ). Isotopic labeled NDMA standard ${ }^{13} \mathrm{C}_{2}-\mathrm{D}_{6^{-}}$ NDMA was purchased from Cambridge Isotope Laboratories (Tewksbury, MA). All other chemicals and reagents were ACS or HPLC grade from Sigma-Aldrich.

Sample Preparation

An entire single metformin tablet was used for sample preparation. One metformin tablet was weighed in a polypropylene tube and methanol was added at approximately $25 \mathrm{mg} \mathrm{API} / \mathrm{mL}$. The sample was then homogenized, centrifuged at 13,000 rpm for 1 minute. The supernatant was filtered through $0.2 \mu \mathrm{m}$ nylon filter. A known amount of ${ }^{13} \mathrm{C}_{2}-\mathrm{D}_{6}-\mathrm{NDMA}$ was spiked into the sample in the LC vial targeting the final internal standard concentration of $40 \mathrm{ng} / \mathrm{mL}$. The sample was then ready for instrumental analysis.

Instrumental Analysis

NDMA in metformin was determined by LC-HRMS, detailed in Valisure's FDA Citizen Petition on Metformin [31]. Briefly, $10 \mu \mathrm{L}$ of sample extract was injected, and chromatographic separation started at gradient of $97.5 \%$ of mobile phase A ( $0.1 \%$ formic acid in water) and $2.5 \%$ of mobile phase $B(0.1 \%$ formic acid in methanol) at $0.3 \mathrm{~mL} / \mathrm{min}$ and was held for 2 minutes. Mobile phase $B$ ramped up to $50 \%$ at 7 minutes and the flow rate was increased to $0.75 \mathrm{~mL} / \mathrm{min}$, followed by $B$ ramped up to $97.5 \%$ at 12 minutes and was held for 0.9 minute. Then mobile phase $B$ ramped down to $2.5 \%$ and was held to 15 minutes. NDMA elutes at 7.48 minutes. Atmospheric pressure chemical ionization mode ( $\mathrm{APCl}+$ ) was selected to ionize NDMA and its isotopic labeled internal standard. Mass identification for NDMA was done by detecting the accurate mass of $[M+1]^{+}$in MRMHR acquisition mode for NDMA $75.0553>75.0553$, and ${ }^{13} \mathrm{C}_{2}-\mathrm{D}_{6}-\mathrm{NDMA} 83.0997>83.0997$, respectively. The mass accuracy was set at 15 parts per million (ppm) and mass resolution was greater than 25,000. Accurate masses of NMBA, NDEA, NDBA, NEIPA, and NDIPA were also monitored in the sample analysis.

Quality Assurance and Quality Control

Linear calibration curve was established by a nine-point calibration ranging from 0.3 to 200 $\mathrm{ng} / \mathrm{mL}$ containing the same internal standard concentration as samples. Calibration is accepted if the $r^{2}$ is equal or greater than 0.99. The limit of quantification (LOQ) is defined as the lowest acceptable calibration point. The lowest calibration point must have a minimum signal to noise ratio of 10. Concentrations of NDMA in samples were quantified by the internal standard method. Isotopic internal standard quantification is widely recommended and practiced by regulatory agencies, analytical industry, and academia in trace level organic compound analysis of complex samples, including NDMA in drinking water [34], wastewater [35], soil [36], food and beverages [37, 38], biological samples [39], and pharmaceutical products [40,41]. Due to the complexity of sample matrices and usually the orders of magnitudes in concentrations between 
medRxiv preprint doi: https://doi.org/10.1101/2020.05.22.20110635; this version posted June 1, 2020. The copyright holder for this preprint (which was not certified by peer review) is the author/funder, who has granted medRxiv a license to display the preprint in perpetuity.

It is made available under a CC-BY-ND 4.0 International license .

NDMA and its sample matrices, the ionization efficiency and mass spectrometry responses to NDMA could be quite different among samples with different compositions, such as IR or ER tablets and tablets from different manufacturers. Internal standard quantification method corrects the analyte concentrations by their respective internal standard recovery, thus overcomes the experimental loss or ion suppression of the target analytes. Quality Control (QC) samples at low, medium, and high concentrations were analyzed by the same analytical procedure as metformin samples. The instrument LOQ was $0.3 \mathrm{ng} / \mathrm{mL}$ for NDMA.

Data Analysis

NDMA levels were scaled according to the common number of tablets taken per day at the recommended maximum adult daily dose of $2000 \mathrm{mg}$ (see Table 1) [43]. A two proportion z-test was used to report statistical confidence.

\section{Results}

128 samples reportedly purchased in 30 states make up this data set (see Table 1).

\begin{tabular}{|r|c|c|c|c|}
\hline $\begin{array}{r}\text { Metformin Unit } \\
\text { Dose }\end{array}$ & $\begin{array}{c}\text { Tablet Scaling } \\
\text { Factor for } \\
\text { Maximum Dose } \\
\text { Per Day }\end{array}$ & $\begin{array}{c}\text { Number of } \\
\text { Immediate } \\
\text { Release Samples }\end{array}$ & $\begin{array}{c}\text { Number of } \\
\text { Extended Release } \\
\text { Samples }\end{array}$ & Total \\
\hline $500 \mathrm{mg}$ & 4 & 37 & 58 & 95 \\
\hline $750 \mathrm{mg}$ & 2 & 0 & 11 & 11 \\
\hline $1000 \mathrm{mg}$ & 2 & 22 & 0 & 22 \\
\hline NDMA Above ADI & -- & $17 \%$ & $52 \%$ & $36 \%$ \\
\hline
\end{tabular}

Table 1. Information and composition of crowdsourced samples tested including the percent of immediate realease and extended release samples with NDMA above the acceptable daily intake (ADI) at maximum tablet dose. The Tablet Scaling Factor is the maximum number of tablets commonly taken per day.

Limit of quantification varied according to tablet weight but was between 7 to $15 \mathrm{ng}$ per sample for all nitrosamines tested. $42 \%$ of samples had detectable levels of NDMA. When scaled to the maximum adult tablet dosage equivalent, $36 \%$ of all samples had NDMA levels that exceed the acceptable daily intake. $52 \%$ of ER samples and $17 \%$ of IR samples had detectable NMDA levels that surpassed the acceptable daily intake limit at maximum tablet dose. Recovery efficiency for isotopically labelled NDMA, however, was also lower for IR samples compared to ER samples with averages of $46.1 \% \pm$ $17.3 \%$ for 69 ER samples, and $42.9 \% \pm 15.7 \%$ for 56 IR samples ( 3 combination metformin product samples were excluded). 
medRxiv preprint doi: https://doi.org/10.1101/2020.05.22.20110635; this version posted June 1, 2020. The copyright holder for this preprint (which was not certified by peer review) is the author/funder, who has granted medRxiv a license to display the preprint in perpetuity. It is made available under a CC-BY-ND 4.0 International license .

This recovery analysis underscores the sample complexity of pharmaceutical products, and the existance of matrix effects in mass spectrometry analysis of trace level chemicals under the influence of other chemicals that are usually thousands times higher than the target contaminants, i.e. nanogram level of NDMA in hundreds of milligrams of API and excipients.

No samples analyzed had detectable levels of the nitrosamines NMBA, NDEA, NEIPA, NDIPA, or NDBA. NDMA levels varied widely across samples (see Figure 1 ).

NDMA in Maximum Dose Equivalent

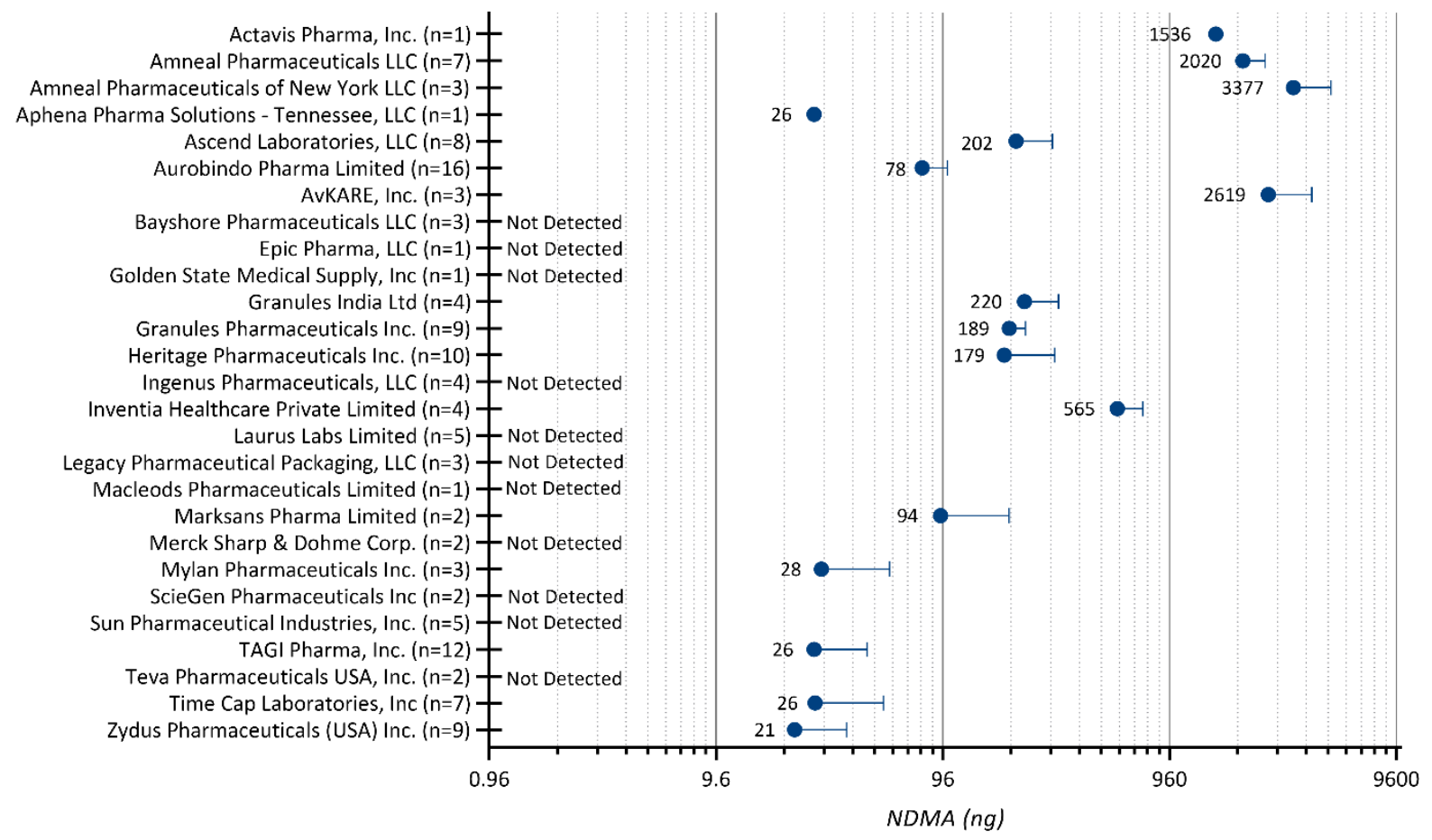

Figure 1. Study samples organized by labeling company and showing the number (n) of samples analyzed. For labeling companies where one or more samples contained detectable levels of NDMA, the average of the samples with NDMA detected are shown in maximum tablet dose equivalent, along with the standard deviation, if applicable.

Detection of high levels of NDMA trends with labeling company and Abbreviated New Drug Application codes (ANDA) (see Figure 2). There are a few examples of specific lablers with multiple ANDAs where samples from one ANDA had detectable NDMA levels and samples from another ANDA did not. There are also examples of specific ANDAs where a few labelers use the same ANDA with some showing detectable NDMA levels and others not. 
medRxiv preprint doi: https://doi.org/10.1101/2020.05.22.20110635; this version posted June 1, 2020. The copyright holder for this preprint (which was not certified by peer review) is the author/funder, who has granted medRxiv a license to display the preprint in perpetuity. It is made available under a CC-BY-ND 4.0 International license .

NDMA in Maximum Dose Equivalent

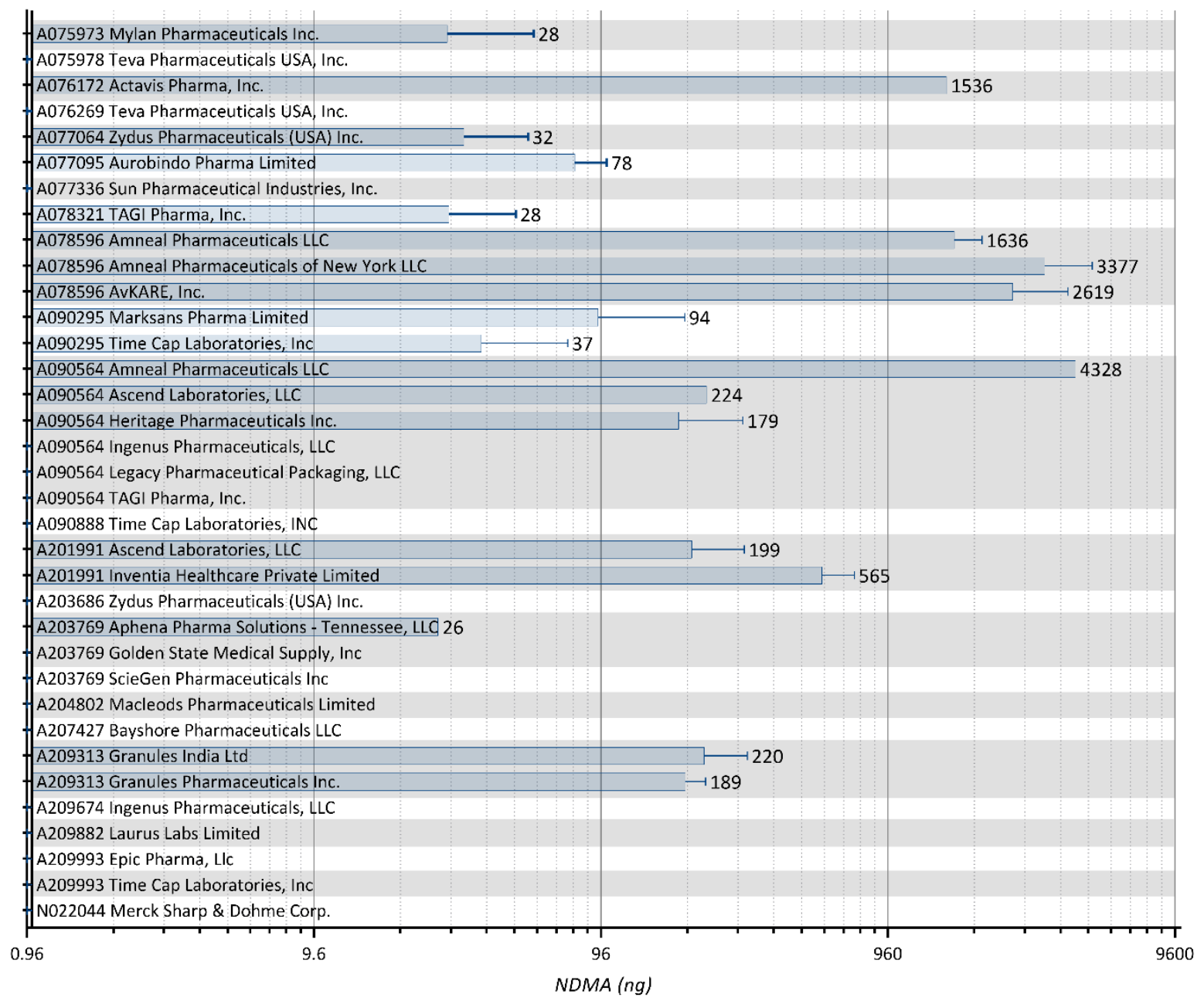

Figure 2. Unique formulations for metformin drug products are organized by ANDA codes and labeling company. For labeling companies where one or more samples contained detectable levels of NDMA, the average of the samples with NDMA detected at maximum daily tablet dose are shown as blue bars. Lines without blue bars did not have samples with detectable levels of NDMA. Alternating grey and white blocks are used to group identical ANDA codes used by different labeling companies.

\section{Discussion and Conclusions}

Quantitative NDMA testing reported here for 128 crowdsourced metformin drug products suggest strong correlation between drug quality and specific National Drug Codes (NDC), which are tied to the company that labels the product for sale in the United States. Of greatest concern are labeling companies with high NDMA levels that exceed the acceptable daily intake (ADI) limit established by the FDA. The exposure to NDMA is compounded by the fact that metformin often treats chronic diseases, and as a result, the cumulative exposure to this contamination for many patients is likely occurring for 
medRxiv preprint doi: https://doi.org/10.1101/2020.05.22.20110635; this version posted June 1, 2020. The copyright holder for this preprint (which was not certified by peer review) is the author/funder, who has granted medRxiv a license to display the preprint in perpetuity. It is made available under a CC-BY-ND 4.0 International license .

many years. Although there appear to be some trends for specific ANDAs and labeling companies, the overall dispersed nature of contamination suggests complexity in the source of the NDMA.

The results reported here are derived from sampling of a limited cross section of crowdsourced onmarket products. Importantly, medications purchased by the government (e.g., Department of Defense, Veterans Health Administration, etc) and dispensed by federal pharmacies may have different purchasing agreements for metformin compared to civilian pharmacies. A phone survey to four federal pharmacies to inquire about the labelers of their current stocks of metformin revealed five companies contained in this study and one not represented in this study, data not shown. Therefore, it is plausible that individuals receiving medications from government sources experience similar contamination issues, but further research is necessary.

Single tablet analysis employed in this study does not provide statistical significance for nitrosamine content results at the lot level or for some NDCs. Only two tablets were requested from each individual to minimize impact on patients' medication regimen. Importantly, $36 \%$ of samples had NDMA levels that exceeded the ADI limit at maximum dosage units per day. This finding is consistent with data from Valisure's FDA Citizen Petition on Metformin [30] reporting 42\% for the same metric for lots tested in triplicate. Interestingly, less instances of NDMA detected above the ADI limit per tablet or when scaled to maximum tablet dose occurred for IR formulations compared to ER formulations $(52 \%$ and $17 \%$ respectively, see Table 1). There were, however, ten IR samples from four different labeling companies that exceeded the ADI at maximum tablet dose (see the supplemental table).

The recovery efficiency of isotopically labelled NDMA was lower for IR samples compared to ER samples which could help explain the lower NDMA detection rate in IR samples. Although the difference between IR and ER was not statistically significant in this study ( $p$ value $=.29$ ), similar isotopic control recovery analysis was performed on the 38 pharmacy batches in Valisure's Citizen Petition which did show a statistically significant difference where IR recovery percentage were lower than $E R$ ( $p$ value $=$ .001) [42]. It is possible that the pharmacy samples in Valisure's Citizen Petition were stored in more stable conditions and had less variability in age than crowdsourced samples, potentially allowing for easier detection of statistical significance between IR and ER. This suggests the differences between cases of concerning NDMA detected in ER versus IR medications may be confounded by release formulation for low levels of NDMA contamination. These results and the overall variability for recovery of NDMA in analysis collectively suggest that inactive ingredients used in both metformin drug product ER and IR formulations interfere with NDMA detection. Internally controlling for recovery in every sample is critical for testing programs. Use of internal standard is strongly recommended in draft version of International Council for Harmonisation Guideline M10 - Bioanalytical Method Validation: "A suitable internal standard (IS) should be added to all calibration standards, QCs and study samples during sample processing" [44]. In addition, developing of more selective sample extraction and cleanup method for nitrosamine analysis can potentially reduce the sample interferences in LC-HRMS analysis.

The distribution of the limited tested products in this study is unable to fully predict the prevalence of product formulations or NDCs that are on market in the US. Rarer drug products containing metformin were predictably absent from this study. For example, 750 and $850 \mathrm{mg}$ immediate release metformin drug products are not commonly prescribed and were not submitted to this study. Likewise, only three combination products that included metformin were submitted. Less commonly prescribed metformin 
medRxiv preprint doi: https://doi.org/10.1101/2020.05.22.20110635; this version posted June 1, 2020. The copyright holder for this preprint (which was not certified by peer review) is the author/funder, who has granted medRxiv a license to display the preprint in perpetuity. It is made available under a CC-BY-ND 4.0 International license .

drug products are of interest since they are likely not manufactured as ubiquitously as 500 and $1000 \mathrm{mg}$ immediate and extended release products.

Despite the aforementioned limitations, this novel approach to crowdsource medication samples for contamination analysis may represent the least biased snapshot of post-market drug quality reasonably possible for metformin drug products. The broad distribution of NDMA contamination levels across metformin products warrants further investigation given the possibility for long-term exposure as a maintenance medication. The highest amount of NDMA detected in this study was $1565 \mathrm{ng}$ in a single $500 \mathrm{mg}$ dosage unit (3.13 parts per million API). If four of these tablets are take per day, as is commonly prescribed, the NDMA exposure would be 65 -times greater than the acceptable daily intake limit established by the FDA. For the NDCs listed in this study showing high levels of NDMA, further investigation and product recalls are warranted to protect the American public from unnecessary exposure to NDMA.

Disclosure: Valisure LLC is a for-profit analytical pharmacy that batch tests and certifies medications prior to direct sale through online pharmacy. The views expressed herein are those of the authors and do not reflect the official policy or position of the U.S. Army Medical Department, the U.S. Army Office of the Surgeon General, the Departments of the Army, Navy, Air Force, the Department of Defense, or the U.S. Government. 
medRxiv preprint doi: https://doi.org/10.1101/2020.05.22.20110635; this version posted June 1, 2020. The copyright holder for this preprint

(which was not certified by peer review) is the author/funder, who has granted medRxiv a license to display the preprint in perpetuity.

It is made available under a CC-BY-ND 4.0 International license .

\section{References}

1. Mayo Clinic. Metformin (Oral Route). 2020; Available from: https://www.mayoclinic.org/drugssupplements/metformin-oral-route/description/drg-20067074.

2. GoodRx. Metformin vs. Metformin ER: Which One Is Right for Me? 2020; Available from: https://www.goodrx.com/blog/metformin-vs-extended-release-metformin-pros-cons/.

3. $\quad$ ClinCalc.com. Metformin Hydrochloride Drug Usage Statistics, United States, 2007 - 2017.; Available from: https://clincalc.com/DrugStats/Drugs/MetforminHydrochloride.

4. Beyond diabetes, metformin may prove to be a 'wonder drug'. 2017.

5. Abdelgadir, E., et al., Effect of Metformin on Different Non-Diabetes Related Conditions, a Special Focus on Malignant Conditions: Review of Literature. J Clin Med Res, 2017. 9(5): p. 388-395.

6. Khokhar, A., et al., Metformin Use in Children and Adolescents with Prediabetes. Pediatr Clin North Am, 2017. 64(6): p. 1341-1353.

7. International Agency for Research on Cancer, IARC MONOGRAPHS ON THE IDENTIFICATION OF CARCINOGENIC HAZARDS TO HUMANS. World Health Organization.

8. Lijinsky, W., E. Conrad, and R. Van de Bogart, Carcinogenic nitrosamines formed by drug-nitrite interactions. Nature, 1972. 239(5368): p. 165-7.

9. Lijinsky, W., Reaction of drugs with nitrous acid as a source of carcinogenic nitrosamines. Cancer Res, 1974. 34(1): p. 255-8.

10. World Health Organization. WHO Information Note UPDATE ON NITROSAMINE IMPURITIES.

11. U.S. Food and Drug Administration, Center for Biologics Evaluation and Research (CBER) M7(R1) Assessment and Control of DNA Reactive (Mutagenic) Impurities in Pharmaceuticals To Limit Potential Carcinogenic Risk Guidance for Industry. 2018.

12. U.S. Food and Drug Administration. Laboratory Tests / Metformin. 2020; Available from: https://www.fda.gov/drugs/drug-safety-and-availability/laboratory-tests-metformin.

13. European Pharmacopeia, 2.4.36. N-NITROSAMINES IN ACTIVE SUBSTANCES. Pharmeuropa 32.2.

14. U.S. Pharmacopeia, General Chapter Prospectus: <1469> Nitrosamine Impurities.

15. U.S. Food and Drug Administration, Statement from Janet Woodcock, M.D., director of FDA's Center for Drug Evaluation and Research, on impurities found in diabetes drugs outside the U.S. 2019.

16. U.S. Food and Drug Administration, FDA Updates and Press Announcements on Angiotensin II Receptor Blocker (ARB) Recalls (Valsartan, Losartan, and Irbesartan). 2019.

17. U.S. Food and Drug Administration, Search List of Recalled Angiotensin II Receptor Blockers (ARBs) including Valsartan, Losartan and Irbesartan. September 2019; Available from: https://www.fda.gov/drugs/drug-safety-and-availability/search-list-recalled-angiotensin-iireceptor-blockers-arbs-including-valsartan-losartan-and.

18. U.S. Food and Drug Administration, FDA Requests Removal of All Ranitidine Products (Zantac) from the Market. 2020.

19. U.S. Food and Drug Administration, FDA Updates and Press Announcements on NDMA in Metformin. 2020; Available from: https://www.fda.gov/drugs/drug-safety-and-availability/fdaupdates-and-press-announcements-ndma-metformin.

20. Health Services Authority of Sinapore, HSA Recalls Three out of 46 Metformin Medicines. 2019.

21. Swissmedic, Trace amounts of a nitrosamine impurity found in individual diabetes medicines. 2019.

22. Government of Canada, Health Canada evaluating NDMA in metformin drugs. 2019.Available from: https://healthycanadians.gc.ca/recall-alert-rappel-avis/hc-sc/2019/71831a-eng.php 
medRxiv preprint doi: https://doi.org/10.1101/2020.05.22.20110635; this version posted June 1, 2020. The copyright holder for this preprint (which was not certified by peer review) is the author/funder, who has granted medRxiv a license to display the preprint in perpetuity. It is made available under a CC-BY-ND 4.0 International license .

23. Swissmedic, Chargenrückruf-Metformin Streuli, Filmtabletten.

24. Government of Canada, Certain Metformin diabetes drugs recalled due to the presence or possible presence of NDMA. 2020.Available from: https://healthycanadians.gc.ca/recall-alertrappel-avis/hc-sc/2020/72287a-eng.php

25. European Medicines Agency, EMA update on metformin diabetes medicines Share. 2019.

26. U.S. Food and Drug Administration, Drug Quality Sampling and Testing Programs. 2020; Available from: https://www.fda.gov/drugs/science-and-research-drugs/drug-quality-samplingand-testing-programs.

27. U.S. Food and Drug Administration, Regulatory Procedures Manual Chapter 6: JUDICIAL ACTIONS. 2020.

28. Regulations.gov, Valisure Citizen Petition on Metformin. 2020.Available from: https://beta.regulations.gov/document/FDA-2020-P-0978-0001

29. U.S. Food and Drug Administration, FDA Alerts Patients and Health Care Professionals to Nitrosamine Impurity Findings in Certain Metformin Extended-Release Products. Available from: https://www.fda.gov/news-events/press-announcements/fda-alerts-patients-and-health-careprofessionals-nitrosamine-impurity-findings-certain-metformin

30. U.S. Food and Drug Administration, Liquid Chromatography-High Resolution Mass Spectrometry (LC-HRMS) Method for the Determination of NDMA in Metformin Drug Substance and Drug Product. 2020.

31. Valisure, Valisure LC-HRMS Method for Determination of NDMA in Metformin. 2020.

32. U.S. Food and Drug Administration, Orange Book: Approved Drug Products with Therapeutic Equivalence Evaluations. 2020.

33. U.S. Food and Drug Administration, National Drug Code Directory. 2020.

34. U.S. Environmental Protection Agency, Method 521, Determination of Nitrosamines in Drinking Water by Solid Phase Extraction and Capillary Column Gas Chromatography with Large Volume Injection and Chemical Ionization Tandem Mass Spectrometry (MS/MS), Version 1.0, September 2004.

35. Ngongang AD, Duy SV, Sauvé S. Analysis of nine N-nitrosamines using liquid chromatographyaccurate mass high resolution-mass spectrometry on a Q-Exactive instrument. Analytical Methods. 2015;7(14):5748-59.

36. Bednar et al., Determination of Low Level NOMA in Soils, U.S. Army Corps of Engineers, ERDC TN-EQT-09-01, December 2009. https://erdclibrary.erdc.dren.mil/jspui/bitstream/11681/3699/1/ERDC-TN-EQT-09-01.pdf

37. Chen et al., High Sensitivity Analysis of Nitrosamines Using GC-MS/MS, ThermoFisher Scientific Application Note 10315.

38. Tipler, A., The Determination of Low Levels of Nitrosamines in Beer Using the Clarus $680 \mathrm{GC} / \mathrm{MS}$ and a D-Swafer System, PerkinElmer Application Note.

39. Zeng $\mathrm{T}$, Mitch WA. Oral intake of ranitidine increases urinary excretion of $\mathrm{N}$ nitrosodimethylamine. Carcinogenesis. 2016 Jun 1;37(6):625-34.

40. U.S. Food and Drug Administration, Combined Direct Injection N-Nitrosodimethylamine (NDMA), N-Nitrosodiethylamine (NDEA), N-Nitrosoethylisopropylamine (NEIPA), NNitrosodiisopropylamine (NDIPA), and N-Nitrosodibutylamine (NDBA) Impurity Assay by GCMS/MS. 2019. https://www.fda.gov/media/123409/download

41. Health Services Authority of Singapore, Determination of N-nitrosodemethylamine (NDMA) in Metformin Products by HRAM-GCMS, Ver002, May 2020. https://www.hsa.gov.sg/docs/defaultsource/announcements/safety-alerts/determination-of-ndma-in-metformin-products-by-hramgcms.pdf 
medRxiv preprint doi: https://doi.org/10.1101/2020.05.22.20110635; this version posted June 1, 2020. The copyright holder for this preprint

(which was not certified by peer review) is the author/funder, who has granted medRxiv a license to display the preprint in perpetuity.

It is made available under a CC-BY-ND 4.0 International license .

42. Valisure, Valisure FDA Citizen Petition Comment Letter (May 31, 2020). Available from: https://www.valisure.com/wp-content/uploads/Valisure-FDA-Citizen-Petition-Comment-LetterMay-31-2020.pdf

43. Prescribing Information, Glumetza (metformin hydrochloride extended-release tablets). 2011.

44. International Council for Harmonisation, Guideline M10, Bioanalytical Method Validation, Draft Version. Available from: https://www.fda.gov/regulatory-information/search-fda-guidancedocuments/m10-bioanalytical-method-validation 


\section{NDMA in Max Dose Equivalent}

Actavis Pharma, Inc. $(n=1)-$ Amneal Pharmaceuticals LLC $(n=7)-$ Amneal Pharmaceuticals of New York LLC $(n=3)+$ Aphena Pharma Solutions - Tennessee, LLC $(n=1)-$

Ascend Laboratories, LLC $(n=8)$ Aurobindo Pharma Limited $(n=16)-$ AvKARE, Inc. $(n=3)-$

Bayshore Pharmaceuticals LLC $(n=3)-$ Not Detected Epic Pharma, LLC $(n=1)-$ Not Detected Golden State Medical Supply, Inc $(n=1)-$ Not Detected Granules India Ltd $(n=4)+$

Granules Pharmaceuticals Inc. $(n=9)-$ Heritage Pharmaceuticals Inc. $(n=10)-$

Ingenus Pharmaceuticals, LLC $(n=4)-$ Not Detected Inventia Healthcare Private Limited $(n=4)-$

Laurus Labs Limited $(n=5)+$ Not Detected Legacy Pharmaceutical Packaging, LLC $(n=3)$ - Not Detected

Macleods Pharmaceuticals Limited $(n=1)$ - Not Detected

Marksans Pharma Limited $(n=2)$

Merck Sharp \& Dohme Corp. $(n=2)-$ Not Detected

Mylan Pharmaceuticals Inc. $(n=3)-$

ScieGen Pharmaceuticals Inc $(n=2)-$ Not Detected

Sun Pharmaceutical Industries, Inc. $(n=5)$ - Not Detected

TAGI Pharma, Inc. ( $n=12)$

Teva Pharmaceuticals USA, Inc. $(n=2)-$ Not Detected

Time Cap Laboratories, Inc $(n=7)$

Zydus Pharmaceuticals (USA) Inc. ( $n=9)$

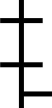

0.96

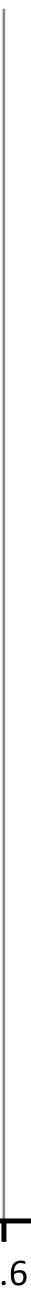

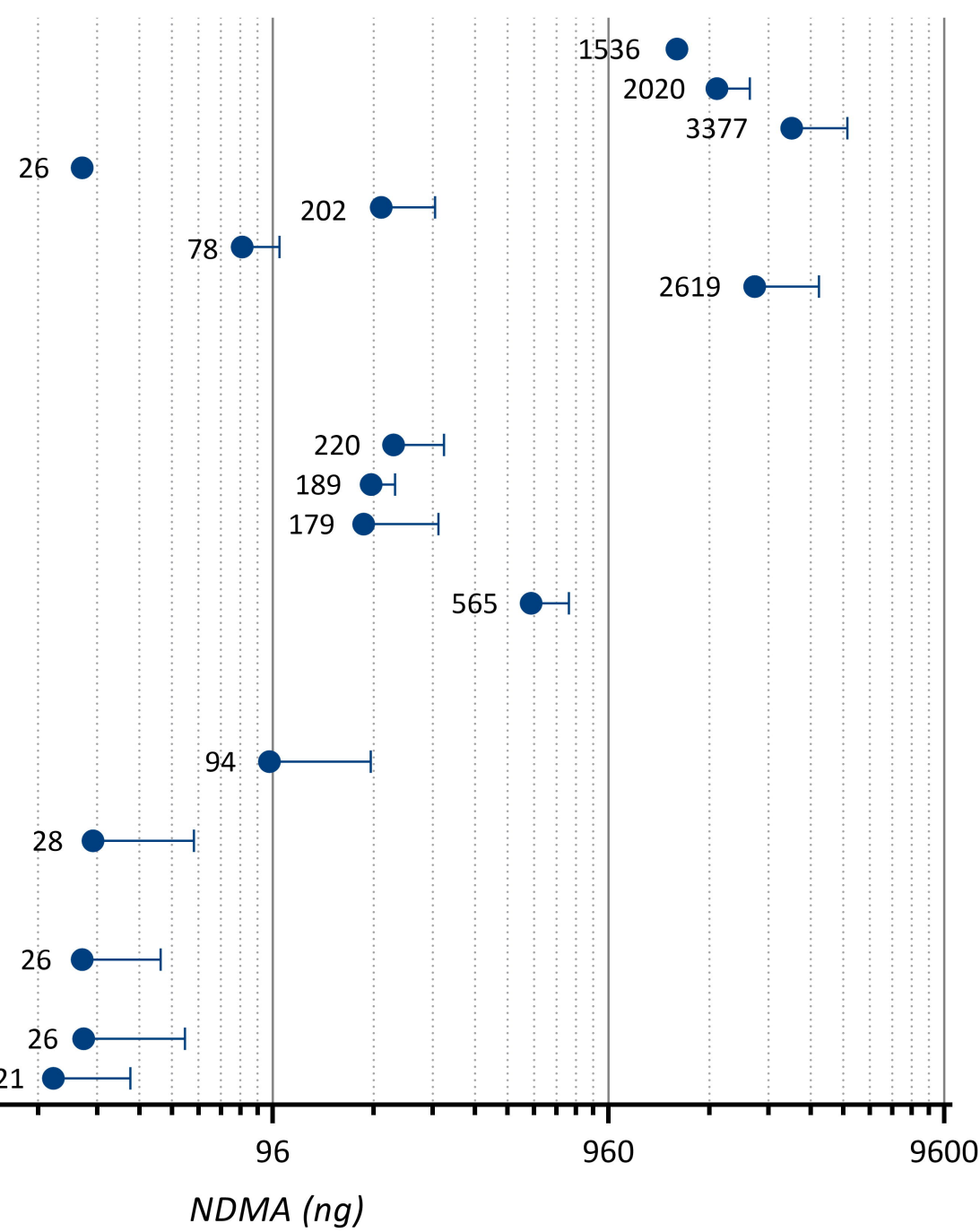


NDMA in Maximum Dose Equivalent

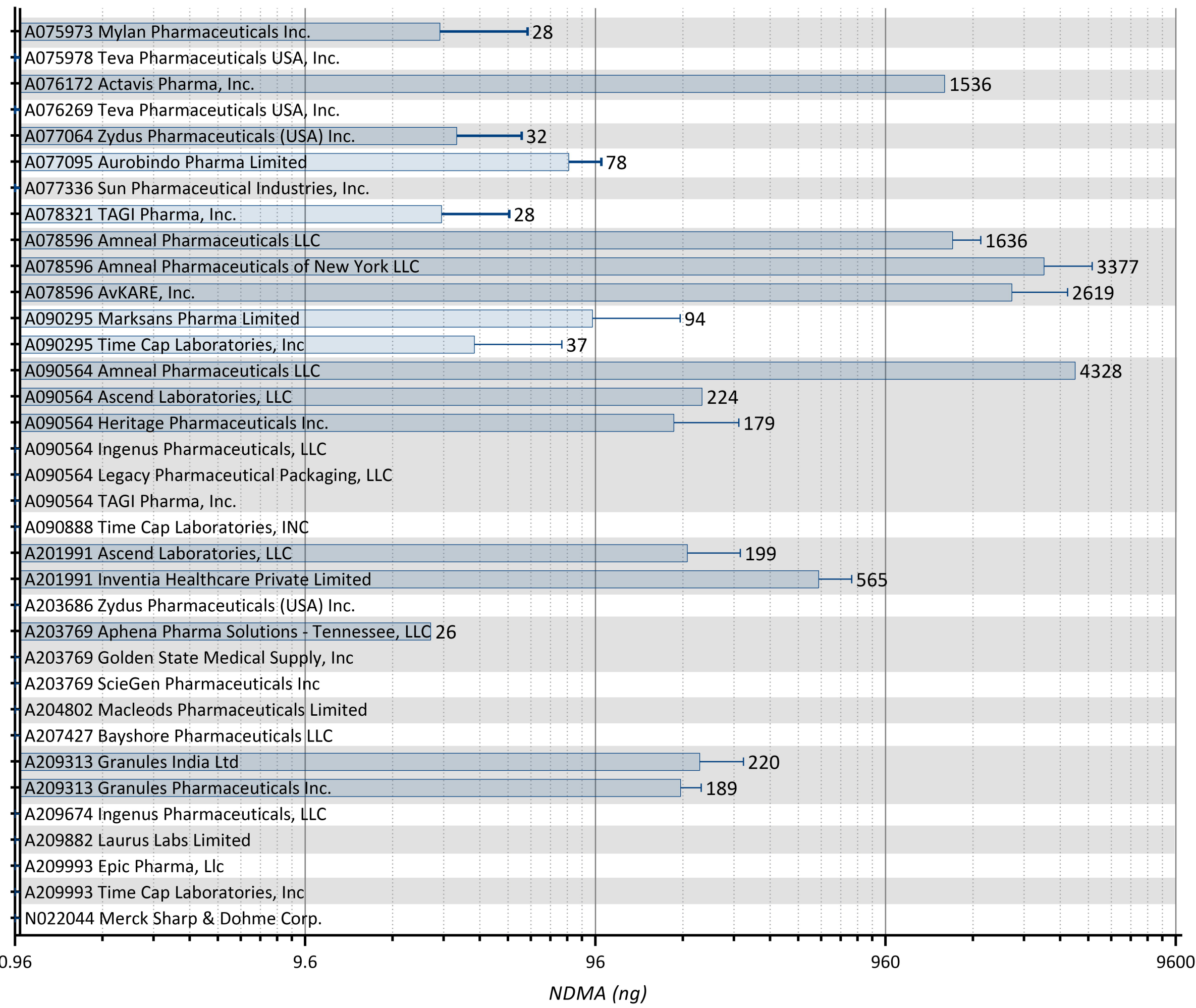

